\title{
Dyslipidemia prevalence in adolescents in public schools
}

\author{
Prevalência de dislipidemia em adolescentes da rede de ensino pública \\ Prevalencia de la dislipidemia en adolescentes de la red de enseñanza pública
}

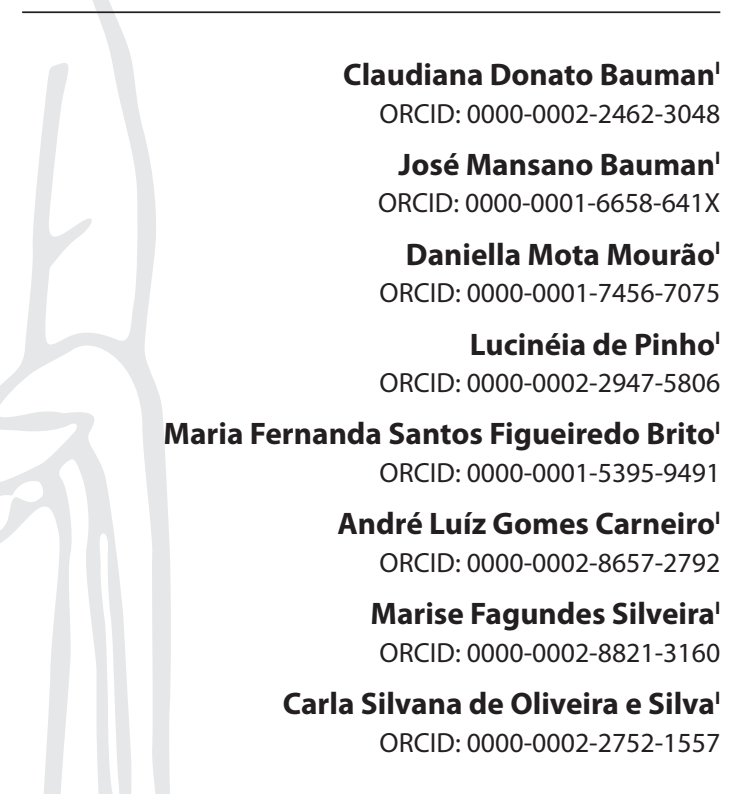

'Universidade Estadual de Montes Claros. Montes Claros, Minas Gerais, Brazil.

How to cite this article:

Bauman CD, Bauman JM, Mourão DM, Pinho L, Brito MFSF, Carneiro ALG, et al. Dyslipidemia prevalence in adolescents in public schools.

Rev Bras Enferm [Internet]. 2020;73(3):e20180523. doi: http://dx.doi.org/10.1590/0034-7167-2018-0523

Corresponding author:

Claudiana Donato Bauman E-mail: caubauman@gmail.com

EDITOR IN CHIEF: Antonio José de Almeida Filho ASSOCIATE EDITOR: Hugo Fernandes

\begin{abstract}
Objective: To evaluate the prevalence of dyslipidemia in adolescents enrolled in the state public education system of the city of Montes Claros, state of Minas Gerais, and compare to a Brazilian population-based study. Method: This is an epidemiological, cross-sectional, and analytical study with a population of 77,833 students from 63 schools, representing four geographic areas of the city. After a sample calculation, information on 635 adolescents from 10 to 16 years of age was assessed and blood collection was conducted for the analysis of biochemical parameters of total cholesterol, triglycerides, LDL-c, and HDL-c. Results: Among the adolescents, $26.8 \%$ showed high levels of total cholesterol, $15.7 \%$ of triglycerides, and $6.5 \%$ of LDL-C, and $40.8 \%$ had low HDL-c levels. Conclusion: Except for HDL-c levels, dyslipidemia prevalence and means in adolescents from Montes Claros, Minas Gerais, were above the levels found in the Brazilian population-based study used as parameter.

Descriptors: Adolescent; Prevalence; Dyslipidemias; Epidemiology; Public Health.
\end{abstract}

\section{RESUMO}

Objetivo: avaliar a prevalência da dislipidemia entre adolescentes matriculados no sistema público de ensino estadual da cidade de Montes Claros - Minas Gerais e comparar com um estudo de base populacional brasileiro. Método: trata-se de um estudo epidemiológico, transversal e analítico, com população composta por 77.833 escolares, oriundos de 63 escolas que representaram quatro regiões geográficas do município. Após o cálculo amostral, foram analisadas informações de 635 adolescentes de 10 a 16 anos e realizada a coleta sanguínea para análise de parâmetros bioquímicos do colesterol total, triglicérides, LDL-c, e HDL-c. Resultados: Entre os adolescentes, 26,8\% apresentaram valores elevados de colesterol total, $15,7 \%$ de triglicérides, $6,5 \%$ de LDL-c e 40,8\% níveis baixos de HDL-c. Conclusão: Com exceção do HDL-c, as médias e a prevalência de dislipidemia investigada em adolescentes provenientes de Montes Claros - MG se encontraram acima dos valores evidenciados no estudo de base populacional brasileiro utilizado como parâmetro. Descritores: Adolescente; Prevalência; Dislipidemias; Epidemiologia; Saúde Pública.

\section{RESUMEN}

Objetivo: Evaluar la prevalencia de dislipidemia entre adolescentes matriculados en el sistema público de enseñanza estatal de Monte Claros - Minas Gerais, comparándolo con un estudio de base poblacional brasileño. Método: Estudio epidemiológico transversal y analítico, con población compuesta por 77.833 estudiantes pertenecientes a 63 escuelas correspondientes a las cuatro regiones geográficas municipales. Realizado el cálculo muestral, se analizó la información de 635 adolescentes de 10 a 16 años. Se practicó extracción sanguínea para análisis de parámetros bioquímicos de colesterol total, triglicéridos, LDL-c y HDL-c. Resultados: El 26,8\% de los adolescentes mostró valores elevados de colesterol total; el 15,7\% tenía los triglicéridos elevados; el 6,5\% mostraba valores altos de LDL-c y el 40,8\%, niveles bajos de HDL-c. Conclusión: Exceptuando el HDL-c, los promedios y la prevalencia de dislipidemia investigada en adolescentes de Monte Claros - MG fueron superiores a los valores evidenciados en el estudio de base poblacional brasileño utilizado como parámetro. Descriptores: Adolescente; Prevalencia; Dislipidemias; Epidemiología; Salud Pública. 


\section{INTRODUCTION}

Dyslipidemia is characterized by metabolic disorders that lead to changes in circulating lipid levels in the body. These are anomalies that increase the levels of total cholesterol (TC), triglycerides (TG), low-density lipoprotein cholesterol (LDL-c), and low-density lipoprotein (LDL), and are also related to reduced levels of high-density lipoprotein cholesterol (HDL-c) ${ }^{(1)}$. Studies have reported an increase of the illness in adolescents, including the risk of developing cardiovascular diseases (CVDs) in adult life $\mathrm{e}^{(2)}$.

The prevalence of dyslipidemia significantly increased worldwide in the last decades ${ }^{(3)}$. These changes are related to epidemiological, demographic, and nutritional transitions that contributed to the development of the outcome ${ }^{(4)}$. A significant increase in the last 10 years took place among Brazilian adolescents, with a prevalence increasing from $3.5 \%$ to $46.8 \%$ (low HDL-c), as reported by the Study of Cardiovascular Risk in Adolescents (ERICA, per its acronym in Portuguese) in 2016 (5-7).

The main risk factors associated with the development of dyslipidemia were family background and, especially, excessive weight gain and subsequent increase in $\mathrm{BMI}^{(4)}$. Among adolescents, these conditions are directly related to poor eating habits and a sedentary lifestyle, causing an impact on subclinical atherosclerosis and the risk of dyslipidemia in adult life and, as a result, the development of atherogenesis ${ }^{(6-9)}$.

The epidemiological assessment of the lipid profile is a potential tool to promote public health policies for the establishment of measures and diagnoses ${ }^{(10-11)}$. In the city of Montes Claros, located in the northern region of the state of Minas Gerais, population studies of the changes of plasma lipid levels in adolescents are still limited. Therefore, the collection of regional data may help with prevention, control, and treatment of dyslipidemia in adolescents.

\section{OBJECTIVE}

To evaluate the prevalence of dyslipidemia in adolescents enrolled in the state public education system in the city of Montes Claros, state of Minas Gerais, and to compare this to a Brazilian population-based study.

\section{METHOD}

\section{Ethical aspects}

The study project was approved by the Ethics Committee of Montes Claros State University (UNIMONTES). After agreement, the participant and researcher signed two copies of a free and informed consent form, according to Resolution 466/12 set up by the National Health Council.

\section{Study design, setting and duration}

This was an epidemiological, cross-sectional, and analytical study. Data were collected in public schools in the city of Montes Claros, state of Minas Gerais, in August 2016 by a trained and coordinated multidisciplinary team.

\section{Population}

The study population consisted of adolescents of both genders, aged 10-16 years, enrolled at the local elementary and high schools in the year 2016. Age stratification was applied for student selection in order to meet the research objectives.

The sample size was established so as to provide an estimation of population parameters with a 0.5 prevalence, which ensured a larger sample size, a 95\% confidence level, and a 5\% sampling error. Finite population correction and effect design correction were carried out, adopting deff equal to 1.5 . A 10\% increase was also established to compensate for possible nonresponses and losses. The estimates showed the need to evaluate and interview at least 634 individuals.

The sample selection process took place in two stages using cluster probability. In the first stage, the involved population was drawn from four areas of city of the Montes Claros: North, South, East, and West. Subsequently, the number of state public schools was listed, quantifying the number of students enrolled by area. In total, 63 schools and 77,833 students were included, and the probability proportional to size (PPS) was applied for the selection of the schools that represented the geographic areas of the city.

In the second stage, the sampling weights as a product of inverse probability weighting for the inclusion of each area were calculated and gauged according to the projected number of students enrolled at schools located in the geographic segments in the year 2016. The sampling weight for the North region was 140 population units (represented by $U_{k}$ ), 109 for the South, 145 for the East, and 97 for the West.

Subsequently, the selection of the adolescents took place, adopting a systematic random sampling. For those refusing to participate were replaced with the previous person on the enrollment list. Thus, the study provided the same opportunity for the adolescents to participate. Each student received instructions and a procedure manual for data collection.

The final sample totaled 635 students and reflected the population. Adolescents that reported kidney, inflammatory, infectious, hepatic, and hematological diseases were excluded, as were those who were pregnant or using medication that would affect their hemodynamic or metabolic profile.

\section{Study protocol}

A sociodemographic questionnaire was used for the evaluation of the variables: gender, age, geographic areas of the city, and a blood test for the analysis of the TC, TG, LDL-C, and HDL-C biochemical parameters.

The values were obtained through blood test by venipuncture, after a 12-hour fasting period, carried out by a reference laboratory. For the biochemical tests, the auto analyzer, Labmax Plenno, from Labtest ${ }^{\oplus}$, was used. The kit used for the measurement of TC, HDL-C, and TG levels was the enzymatic - Trinder - and the enzymatic colorimetric method. LDL-c was measured using the Friedewald equation: $\mathrm{LDL}-\mathrm{c}=$ total cholesterol $-(\mathrm{HDL}-\mathrm{c}+$ triglycerides/5). TG above $400 \mathrm{mg} / \mathrm{dL}$ was excluded, since the formula for this condition was not applied, taking into consideration the mixed hyperlipidemia when TC $>200 \mathrm{mg} / \mathrm{dL}^{(1)}$. 
The collected biological material was properly identified (individualized entry), according to the procedures for composition and integrity of the preanalytical, handling, transportation, and storage phases.

The cutoff points followed the reference values proposed for the ages of 2 to 19 years, according to the Fifth Brazilian Guidelines for Dyslipidemia and Atherosclerosis Prevention (2013), in $\mathrm{mg} / \mathrm{dL}$ : TC: recommended <150, bordering 150-169, and high $\geq 170$; TG: <100, 100-129, and $\geq 130$; LDL-c: <100, 100-129, and $\geq 130$; and HDL-c: recommended $\geq 45$. ${ }^{(1)}$ The term "dyslipidemia" was applied when any change in lipids (lipoproteins), whether isolated or combined, was observed ${ }^{(7)}$.

\section{Analysis of results and statistics}

The data were processed and analyzed using Statistical Package for the Social Sciences (SPSS) software, version 20.0. The numerical variables were described by mean, median, and standard deviation, and the categories by rate. The TC, TG, LDL-C, and HDL-C variables followed the recommendations of the Fifth Brazilian
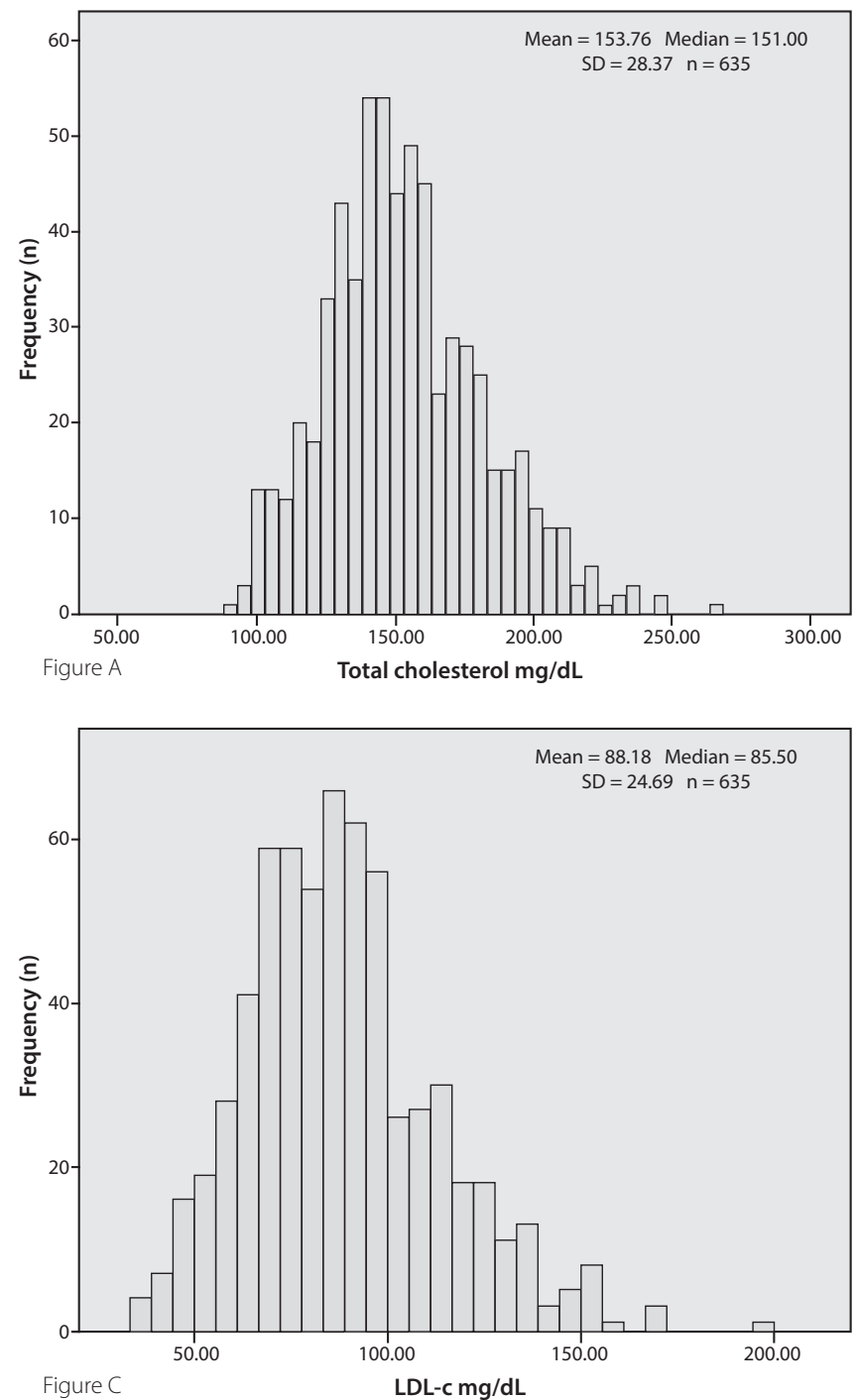

Guidelines for Dyslipidemia and Atherosclerosis Prevention (2013) (1). The means with $95 \%$ confidence intervals for the biochemical variables were also measured, according to students' gender and age. Regarding prevalence, changes in the TC, TG, LDL-C, and HDL-c parameters were checked, according to the areas of Montes Claros, MG.

\section{RESULTS}

Of the 635 adolescents participating in the study, $60.2 \%$ were female, and a plurality (40.8\%) were 14 and 15 years old. Dyslipidemia prevalence among the studied adolescents was $26.8 \%$ for higher TC values and 15.7\% for TG. As for LDL-C, 6.5\% showed undesirable values, and $40.8 \%$ had low HDL-c levels (Table 1).

The mean and median distributions of the serum lipid levels are illustrated in Figure 1 for more comprehensive viewing. The TC mean and median were 153.8 and $151.00 \mathrm{mg} / \mathrm{dL}(\mathrm{A})$, respectively; for TG, they were 94.3 and $89.50 \mathrm{mg} / \mathrm{dL}$ (B), respectively; for LDL-C, they were 88.2 and $85.50 \mathrm{mg} / \mathrm{dL}(\mathrm{C})$, respectively; and for HDL-C, they were 47.3 and $46.00 \mathrm{mg} / \mathrm{dL}(\mathrm{D})$, respectively.
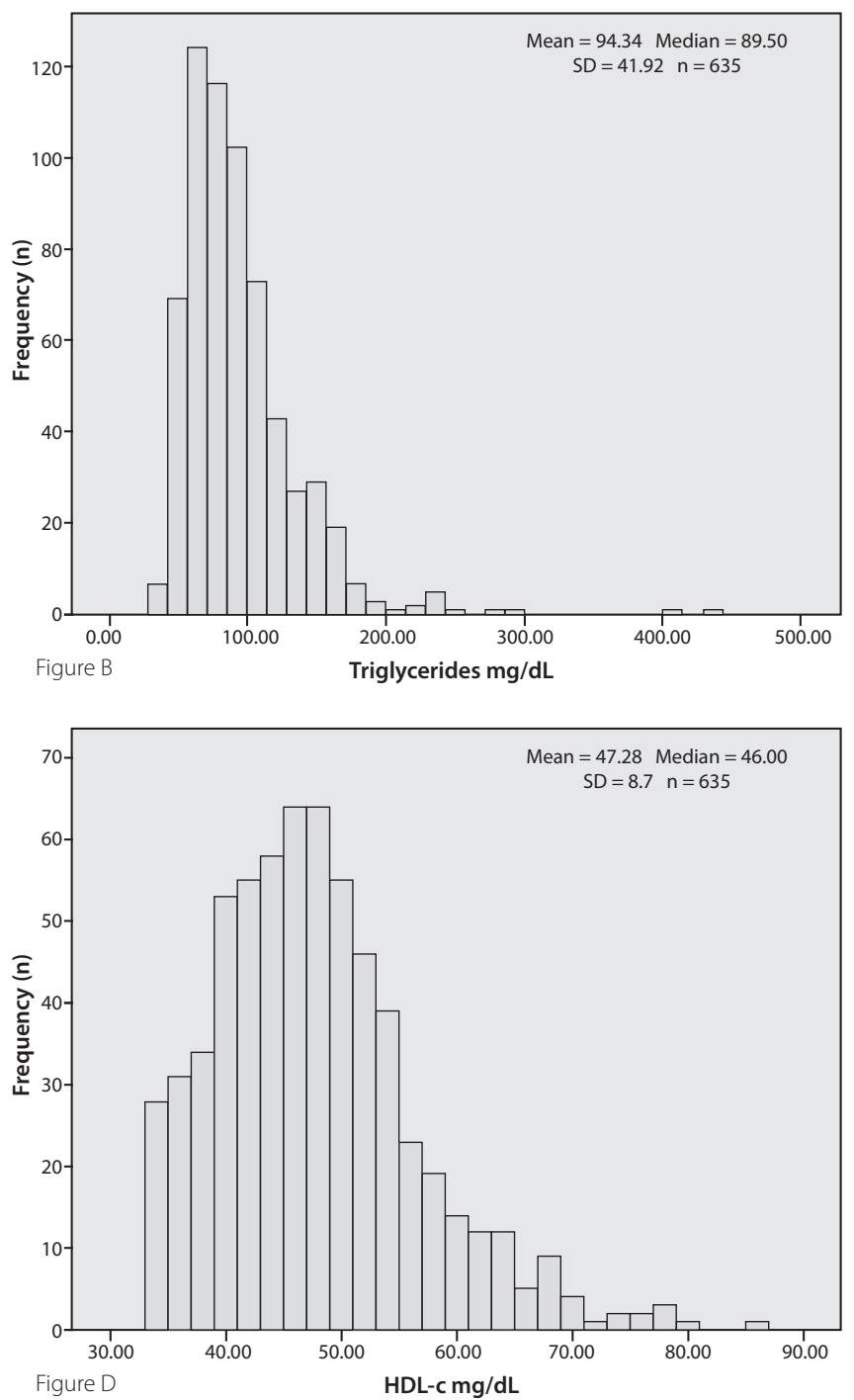

Figure 1 - Means and medians of the TC, TG, LDL-c HDL-c serum levels of the city of Montes Claros, Minas Gerais, Brazil 
Table 1 - Sample distribution by gender; age group; geographic area of Montes Claros (Minas Gerais, Brazil); percentage of total cholesterol (TC), triglycerides (TG), low-density lipoprotein cholesterol (LDL-c), high-density lipoprotein cholesterol (HDL-c) and $p$-value

\begin{tabular}{|c|c|c|c|c|}
\hline Variable & $\begin{array}{l}\text { Male } \\
\mathrm{n}(\%)\end{array}$ & $\begin{array}{l}\text { Female } \\
\text { n (\%) }\end{array}$ & $\begin{array}{c}\text { Total } \\
\text { n*635 (\%) }\end{array}$ & $\underset{\text { value }^{* *}}{p}$ \\
\hline \multicolumn{5}{|l|}{ Age group } \\
\hline $10-11$ years & $37(13.9)$ & $50(13.1)$ & $87(13.4)$ & 0.111 \\
\hline $12-13$ years & $85(33.9)$ & $89(23.2)$ & $174(27.4)$ & \\
\hline $14-15$ years & $94(37.3)$ & $165(44.0)$ & $259(41.4)$ & \\
\hline 16 years & $37(14.9)$ & $78(19.7)$ & $115(17.8)$ & \\
\hline Area & & & & 0.000 \\
\hline North & $34(16.1)$ & $85(25.9)$ & $119(22.1)$ & \\
\hline South & $77(28.4)$ & $103(24.5)$ & $180(26.0)$ & \\
\hline East & $54(26.5)$ & $82(26.5)$ & $136(26.2)$ & \\
\hline West & $88(28.9)$ & $112(23.7)$ & $200(25.7)$ & \\
\hline Total cholesterol & & & & 0.317 \\
\hline$<150$ & $131(53.4)$ & $176(46.4)$ & $307(49.1)$ & \\
\hline 150 to 169 & $56(21.5)$ & $102(27.1)$ & $158(24.9)$ & \\
\hline$\geq 170$ & $66(25.1)$ & $104(26.5)$ & $170(26.8)$ & \\
\hline Triglycerides & & & & 0.008 \\
\hline$<100$ & $177(70.1)$ & $241(63.2)$ & $418(65.9)$ & \\
\hline 100 to 129 & 34 (13.3) & $83(21.7)$ & $117(18.4)$ & \\
\hline$\geq 130$ & $42(16.6)$ & $58(15.1)$ & $100(15.7)$ & \\
\hline $\begin{array}{l}\text { Low-density lipoprotein } \\
\text { cholesterol }\end{array}$ & & & & 0.662 \\
\hline$<100$ & $189(75.5)$ & $280(73.1)$ & $469(74.0)$ & \\
\hline 100 to 129 & $50(19.0)$ & 75 (19.4) & $125(19.2)$ & \\
\hline$\geq 130$ & $14(5.5)$ & $27(7.6)$ & $41(6.5)$ & \\
\hline $\begin{array}{l}\text { High-density lipoprotein } \\
\text { cholesterol }\end{array}$ & & & & 0.260 \\
\hline Recommended $(>45)$ & $138(54.3)$ & $238(62.4)$ & $376(59.2)$ & \\
\hline Undesired $(<45)$ & $115(45.7)$ & $144(37.6)$ & $259(40.8)$ & \\
\hline
\end{tabular}

According to Table 2, the values showed a higher prevalence of dyslipidemia in females; however, $\mathrm{HDL}$-c was better when compared to males. Relating to the age group of adolescents aged 10-13 years, the mean of the serum levels was higher when compared to older adolescents. The same did not happen with LDL-c, in which the means were very close. When considering the lipid changes of the studied population (the sum of threshold values with the higher ones), it became clear that $51.7 \%$ of the adolescents had altered plasma lipid levels.

Table 3 corresponds to the results obtained in the city of Montes Claros compared with the data presented by the ERICA study, entitled "Prevalence of dyslipidemia in Brazilian adolescents," covering five regions of the country in the year 2016.(5) Although Montes Claros lies in the state of Minas Gerais, located in the southeast of Brazil, its geographic location is more to the north of the state, very close to Brazil's northeast region. The results showed that the means and prevalence in Montes Claros are above the national means and prevalence identified by the Brazilian population study used as a parameter. The exception was HDL-c, which showed exactly similar means and a lower prevalence compared to the remaining Brazilian regions, except the South region.

\section{DISCUSSION}

The prevalence and means of the altered plasma serum levels related to TC, LDL-C, and TG among adolescents of Montes Claros are higher than the results obtained in other Brazilian regions. It is possible to observe the differences between the means through the $(95 \%)$ confidence intervals of the studies.

Table 2 - Mean and prevalence $(95 \% \mathrm{Cl})$ of threshold and higher plasma lipid levels by gender, age group, and total population estimated with change

\begin{tabular}{|c|c|c|c|c|c|c|c|}
\hline \multirow{2}{*}{ Lipids } & \multicolumn{2}{|c|}{ Mean } & \multicolumn{2}{|c|}{ Threshold } & \multicolumn{2}{|c|}{ Higher } & \multirow{2}{*}{$\begin{array}{l}\text { Population of Montes Claros, Minas } \\
\text { Gerais, estimated with change }\end{array}$} \\
\hline & $\mathrm{mg} / \mathrm{dl}$ & $95 \% \mathrm{Cl}$ & $\%$ & $95 \% \mathrm{Cl}$ & $\%$ & $95 \% \mathrm{Cl}$ & \\
\hline \multicolumn{8}{|l|}{ Total cholesterol } \\
\hline All & 153.8 & $151.5-156.0$ & 24.9 & $21.5-28.3$ & 26.8 & $23.5-30.3$ & $40,239(51.7 \%)$ \\
\hline Male & 152.3 & 148.9-155.7 & 22.1 & $20.5-23.7$ & 26.1 & $20.7-31.5$ & \\
\hline Female & 154.7 & 151.7-157.7 & 26.7 & $25.3-28.1$ & 27.2 & $22.7-31.7$ & \\
\hline \multicolumn{8}{|l|}{ Age group } \\
\hline 10-11 years & 157.3 & $151.2-163.5$ & 33.3 & $23.4-43.2$ & 26.4 & $17.1-35.7$ & \\
\hline $12-13$ years & 156.0 & $151.8-160.3$ & 20.1 & $14.2-26.1$ & 30.5 & $23.7-37.3$ & \\
\hline $14-15$ years & 150.7 & $147.5-153.9$ & 26.6 & $21.2-32.0$ & 23.2 & $18.1-28.3$ & \\
\hline 16 years & 154.6 & $148.6-160.5$ & 21.7 & $14.2-29.2$ & 29.6 & $21.3-37.9$ & \\
\hline \multicolumn{8}{|l|}{ Triglycerides } \\
\hline All & 94.3 & $91.1-97.6$ & 18.4 & $15.4-21.4$ & 15.7 & $12.9-18.5$ & $26,541(34.1 \%)$ \\
\hline Male & 90.8 & $85.4-96.3$ & 13.4 & $12.1-14.7$ & 16.6 & $15.2-18.1$ & \\
\hline Female & 96.7 & $92.6-100.7$ & 21.7 & $20.4-23.0$ & 15.2 & $14.1-16.3$ & \\
\hline $10-11$ years & 99.6 & $91.5-107.7$ & 24.1 & $15.1-33.1$ & 21.8 & $13.1-30.5$ & \\
\hline $12-13$ years & 99.6 & $92.3-106.9$ & 19.0 & $13.2-24.8$ & 20.7 & $14.7-26.7$ & \\
\hline $14-15$ years & 90.2 & $85.3-95.0$ & 14.7 & $10.4-19.0$ & 12.4 & $8.4-16.4$ & \\
\hline 16 years & 91.9 & $84.9-98.8$ & 21.7 & $14.2-29.2$ & 11.3 & $5.5-17.1$ & \\
\hline \multicolumn{8}{|l|}{ LDL-C } \\
\hline All & 88.2 & $86.2-90.1$ & 19.7 & $16.6-22.8$ & 6.5 & $61.3-68.7$ & $5,059(26.2 \%)$ \\
\hline Male & 87.8 & $84.8-90.9$ & 19.8 & $18.3-21.4$ & 5.5 & $53.1-56.9$ & \\
\hline Female & 88.4 & $85.8-90.9$ & 19.6 & $18.3-20.9$ & 7.1 & $69.7-72.4$ & \\
\hline 10-11 years & 87.3 & $81.6-92.9$ & 17.2 & $9.3-25.1$ & 6.9 & $59.3-78.7$ & \\
\hline $12-13$ years & 89.3 & $85.4-93.1$ & 21.3 & $15.2-27.4$ & 6.3 & $55.8-70.2$ & \\
\hline $14-15$ years & 88.4 & $85.4-91.4$ & 20.5 & $15.6-25.4$ & 6.9 & $63.4-74.6$ & \\
\hline 16 years & 86.7 & $82.6-90.8$ & 17.4 & $10.5-24.3$ & 5.2 & $42.9-61.1$ & \\
\hline HDL-C & & & $\%$ Low & & & & \\
\hline Male & 47.3 & $46.6-48.0$ & 40.8 & $37.0-44.6$ & - & - & $31,755(40.8 \%)$ \\
\hline Female & 46.5 & $45.5-47.6$ & 45.5 & $43.6-47.4$ & - & - & \\
\hline 10-11 years & 47.8 & $46.9-48.7$ & 37.7 & $36.2-39.2$ & - & - & \\
\hline $12-13$ years & 47.0 & $45.1-48.9$ & 41.4 & $31.1-51.8$ & - & - & \\
\hline $14-15$ years & 46.4 & $45.2-47.6$ & 45.4 & $38.0-52.8$ & - & - & \\
\hline 16 years & 47.9 & $46.8-49.0$ & 39.5 & $33.6-45.5$ & - & - & \\
\hline 16 anos & 47.5 & $45.8-49.2$ & 36.5 & $27.7-45.3$ & - & - & \\
\hline
\end{tabular}


Table 3 - Means and prevalence $(95 \% \mathrm{Cl})$ of dyslipidemia among students of the city of Montes Claros, Minas Gerais, Brazil, compared to the levels presented by the Study of Cardiovascular Risk in Adolescents (ERICA)

\begin{tabular}{lcccccccc}
\hline & $\begin{array}{c}\text { Montes Claros - MG } \\
\text { Means } \mathbf{~ m g / d L ~ ( 9 5 \% ~ C l ) ~}\end{array}$ & $\begin{array}{c}\text { National } \\
\text { \% }\end{array}$ & $\begin{array}{c}\text { Montes Claros } \\
\text { \% }\end{array}$ & $\begin{array}{c}\text { Southeast } \\
\%\end{array}$ & $\begin{array}{c}\text { Central West } \\
\%\end{array}$ & $\begin{array}{c}\text { Northeast } \\
\%\end{array}$ & $\begin{array}{c}\text { North } \\
\%\end{array}$ & $\begin{array}{c}\text { South } \\
\%\end{array}$ \\
\hline TC & $153.8(151.5-156.0)$ & $148.1(147.1-149.1)$ & 26.8 & 20.0 & 23.5 & 18.8 & 16.5 \\
TG & $94.3(91.1-97.6)$ & $77.8(76.5-79.2)$ & 15.7 & 6.8 & 8.7 & 9.4 & 9.6 & 8.2 \\
LDL-C & $88.2(86.2-90.1)$ & $85.3(84.5-86.1)$ & 6.5 & 3.7 & 4.3 & 3.3 & 2.7 & 3.5 \\
HDL-C & $47.3(46.6-47.9)$ & $47.3(46.7-47.9)$ & 40.8 & 45.9 & 46.2 & 51.6 & 58.7 & 36.9 \\
\hline
\end{tabular}

Source: Faria-Neto (2016).

Cultural characteristics in the northern part of the state of Minas Gerais are a result of natural-demographic aspects related to historical processes of settlement and, quintessentially, are based on typical traditional cuisine, having as key elements food with high calories enriched by regional traditions. ${ }^{(12)}$ The studied sample showed that $51.7 \%$ of the respondents had altered TC (the sum of the threshold values and higher ones), and the prevalence of low HDL-c levels was lower (40.8\%) compared to other Brazilian regions, except the South region (36.9\%).

This altered lipid profile has been thoroughly investigated due to its extensive association with atherogenesis. Several population studies, ${ }^{(13-15)}$ since the classics of Framingham, the Multiple Risk Factor Intervention Trial (MRFIT), and the Bogalusa Heart Study, showed this relationship, which has become a global health issue and an imminent threat to the development and health of the global population. ${ }^{(16)}$

During adolescence, changes in serum lipid levels can be predictive of cardiovascular events in adult life. In one phenomenon, called tracking, a propensity of children and adolescents to maintain the same cholesterol levels up to adult life was identified. ${ }^{(17-18)}$ The progression of the condition and the severity of the injuries caused by atherosclerosis may appear in the first decade of life, proportionally with several risk factors, such as dyslipidemia. ${ }^{(14,19)}$

Regarding female adolescents, most of the metabolic parameters found in this study were above the levels in males, which are results similar to a study carried out with adolescents in the city of Pernambuco. ${ }^{(20)}$ Several studies in this area have underlined this result in females. ${ }^{(21-22)}$ According to the I Guidelines for Preventing Atherosclerosis in Childhood and Adolescence (2005), ${ }^{(23)}$ the lipid profile differs in both genders because of sexual maturation, and it may go through variations during the period of growth and development, with variations based on age and sexual hormones.

In this study, the largest percentage of high TC, LDL-C, and TG levels was detected in the 10-11 age group. These data corroborate several scientific studies. ${ }^{(5,21,24)}$ The high prevalence of hypercholesterolemia in early adolescence may occur because of the sexual maturation process. A study that found a link between sexual maturation and high TC levels showed that prepubescent children have a higher probability of developing dyslipidemia compared with postpubescent children (since there is a concentration of sexual hormones and greater body fat storage in this age group). ${ }^{(25)}$ The study used for comparison did not mention the sexual maturation classification of the participants.

Regarding low HDL-c levels, the current study showed that the higher prevalence (45.4\%) and the lower mean $46.4(\mathrm{mg} / \mathrm{dL})$ of this lipoprotein occurred among adolescents in the 12-13 age group; this matches the population-based study. ${ }^{(5)}$ It also showed that the HDL-c mean among Brazilian adolescents was $47.3 \mathrm{mg} /$ $\mathrm{dL}$, which corroborates the values presented in this study, with results that reinforce the reliability of the data presented by the Brazilian population-based study.

Taking into account the prevalence of changes in TC levels (51.7\%), a study carried out with adolescents from different parts of the rural area of Santa Cruz do Sul, state of Rio Grande do Sul, also showed inappropriately high TC levels (54.2\%). ${ }^{(26)}$ The study used as parameter showed changes in $44.3 \%$ of the adolescents, providing a difference of $7.4 \%$ more of adolescents diagnosed in northern Minas Gerais.

When comparing the prevalence of undesired LDL-c levels (6.5\%) shown in the city of Montes Claros with the values found by the population-based study (3.6\%), the value in the levels of this study almost doubled. ${ }^{(5)}$ In the city of Barbacena (Minas Gerais), results that corroborate this investigation were found in a study carried out among students aged 10-19 years from public and private schools, in which undesired levels of LDL-c in $6.6 \%$ of the participants were presented. LDL-c is responsible for carrying cholesterol and triglycerides from the blood to the tissues, which facilitates the buildup of fat plaques in the blood vessels. ${ }^{(27-28)}$

From this perspective, although the reported changes in lipid in relation to higher $\mathrm{LDL}-\mathrm{c}(\geq 130 \mathrm{mg} / \mathrm{dL})$ are less frequent, the finding of a $6.5 \%$ prevalence in the city of Montes Claros must be taken with due consideration by specialists in this field.

The TG mean in Montes Claros was $94.34 \mathrm{mg} / \mathrm{dL}$, and was higher than the national mean $(77.8 \mathrm{mg} / \mathrm{dL})$. The Fifth Brazilian Guidelines of Dyslipidemia and Atherosclerosis Prevention (2013) stressed that TG is the main source of fat that comes from food, and is directly related to potential atherogenic of LDL-c. The higher the level of TG, higher the penetrating capacity of LDL-c into the blood vessels; the atheroma plaque formation occurs due to its oxidation. ${ }^{(1)}$

Regarding the overall means of plasma lipid levels found in the current study, except for HDL-c, they were above the values found at the national level. Despite some differences being detected in relation to the population study, the dichotomous data underscore the importance of creating strategies to tackle dyslipidemia, keeping in mind the increase of TC associated with TG and/or LDL-C, including the isolated decline in HDL-C, which are key risk indicators for developing cardiovascular disease.

$\mathrm{HDL}-\mathrm{c}$ is responsible for the reverse path of LDL-C, since it has the capacity to remove cholesterol from tissues and send it to the liver, where is excreted by the small bowel, which plays a protective role for the vascular bed against atherogenesis. ${ }^{(1)}$ The current study emphasized that the prevalence of HDL-c levels among students from the city of Montes Claros, Minas Gerais, 
was $40.8 \%$, thus showing that they are below those of other compared regions, except for the South region..$^{(5)}$

From this perspective, the fact that the prevalence of HDL-c is below that of other regions may be due to the fact that schools in the surrounding areas do not sell food products. Studies show that low HDL-c levels are commonly found in industrialized societies. The consumption of high-calorie foods and a decline in physical activity are related to lifestyles that are linked to the use of technology, leading to a nutritional profile harmful to adolescents, thus paralleling overweight and the development of metabolic diseases. ${ }^{(29-31)}$

According to the recommendations of the State Secretary of Education (SEE, per its acronym in Portuguese) in the state of Minas Gerais, the meals prepared for students in the public schools meet the recommendations of the National Fund of Education Development (FNDE, per its acronym in Portuguese), taking into account the nutritional parameters, preparation, consistency, storage, and conservation of food consumed in the schools. ${ }^{(32-33)}$

Taking into consideration that overweight is reflected in metabolic changes related to one's lipid profile, ${ }^{(3)}$ strategies to tackle inappropriate eating habits and sedentism must become a priority, especially among obese adolescents, since it is estimated that $42 \%$ show lipid abnormalities, notably those with visceral fat, creating a group at high risk for the development of cardiovascular disease. ${ }^{(7,34-36)}$

In dyslipidemia, in both primary and secondary cases, nutritional adequacy and increasing the levels and regularity of physical activity have the capacity to provide an increase in enzymes associated with the metabolism of lipids, which helps to rebalance them. ${ }^{(37-39)}$

\section{Study limitations}

As study limitation, the criteria for exclusion and the 12-hour fasting for blood collection were self-reported.

\section{Contributions for the areas of nursing, healthcare, or public policy}

The data presented in this study may help to develop intervention strategies related to public health. The fight against the triggering factors of dyslipidemia and the association with other pathologies must be the target of primary care for adolescents. Healthy behaviors have the capacity to lower risks in adult life.

School is a perfect institutional space for social life that embraces students during a relevant part of their lives. A well-informed adolescent may serve as a multiplier and a motivator of changes for their families and peer groups, fostering new habits related to a healthy lifestyle. The results obtained in this study were forwarded to the adolescents, including the reports and necessary guideline for each result.

\section{CONCLUSION}

The prevalence of low HDL-c levels (40.8\%) was lower than the prevalence shown in other Brazilian regions, except for the South region; in addition, regarding the $\mathrm{HDL}-\mathrm{c}$ mean $(47.3 \mathrm{mg} / \mathrm{dL})$, these levels match the data presented in the population-based study, which was used as parameter for this research. The remaining results showed that the means and prevalence of dyslipidemia among adolescents from the city of Montes Claros were above the values found in the Brazilian study.

\section{FUNDING}

This work was supported by the Incentive Factor for the Development of University Teaching and Research in Health and the Graduate Health Science Program of Montes Claros State University.

\section{REFERENCES}

1. Xavier HT, Izar MC, Faria Neto JR, Assad MH, Rocha VZ, Sposito AC, et al. Sociedade Brasileira de Cardiologia. V Diretriz brasileira de dislipidemia e prevenção da aterosclerose. Arq Bras Cardiol [Internet]. 2013[cited 2018 May 02];101(4supl.1):1-36. Available from: http:// www.scielo.br/pdf/abc/v101n4s1/v101n4s1.pdf

2. Simão AF, Précoma DB, Andrade JP, Filho HC, Saraiva JFK, Oliveira GMM. I Cardiovascular Prevention Guideline of the Brazilian Society of Cardiology - Executive Summary. Arq Bras Cardiol[Internet]. 2014[cited 2018 May 02];102(5):420-31. Available from: http://www.scielo.br/ pdf/abc/v102n5/0066-782X-abc-102-05-0420.pdf

3. Lozano P, Henrikson NB, Morrison CC, Dunn J, Nguyen M, Blasi P, et al. Lipid screening in childhood for detection of multifactorial dyslipidemia: a systematic evidence review for the US Preventive Services Task Force. Evidence Synthesis No. 140 [Internet]. Rockville, MD: Agency for Healthcare Research and Quality 2016[cited 2018 May 02];AHRQ Publication No. 14-05204-EF-1. Available from: https://www. ncbi.nlm.nih.gov/pubmedhealth/PMH0089063/pdf/PubMedHealth_PMH0089063.pdf

4. Alcântara Neto OD, Silva RC, Assis AM, Pinto JE. Factors associated with dyslipidemia in children and adolescents enrolled in public schools of Salvador, Bahia. Rev Bras Epidemiol [Internet]. 2012[cited 2018 May 02];15:335-45. Available from: http://www.scielo.br/pdf/rbepid/ v15n2/11.pdf

5. Faria Neto JR, Bento VFR, Baena CP, Olandoski M, Gonçalves LG, Abreu GA, et al. ERICA: prevalence of dyslipidemia in Brazilian adolescents. Rev Saúde Pública [Internet]. 2016[cited 2018 May 02];50:supl.1-10s. Available from: http://www.scielo.br/pdf/rsp/v50s1/0034-8910rsp-S01518-87872016050006723.pdf

6. Pereira PB, Arruda IKG, Cavalcanti AMTS, Diniz AS. Lipid Profile of Schoolchildren from Recife, PE Arq Bras Cardiol [Internet]. 2010 [cited 2018 May 02];95(5):606-13. Available from: http://www.scielo.br/pdf/abc/v95n5/aop13210.pdf

7. Ribas SA, Silva LCS. Fatores de risco cardiovascular e fatores associados em escolares do Município de Belém, Pará, Brasil. Cad Saúde Pública. 2014;30(3):577-86 doi: 10.1590/0102-311X00129812 
8. Lewington S, Whitlock G, Clarke R, Sherliker P, Emberson J, Halsey J, et al. Blood cholesterol and vascular mortality by age, sex, and blood pressure: a meta-analysis of individual data from 61 prospective studies with 55,000 vascular deaths. Lancet [Internet]. 2007 [cited 2018 May 02];370(9602):1829-39. Available from: http://www.thelancet.com/journals/lancet/article/PIIS0140-6736(07)61778-4/fulltext

9. Reuter CP, Silva PT, Renner JD, Mello ED, Valim AR, Pasa L, et al. Dyslipidemia is associated with unfit and overweight-obese children and adolescents. Arq Bras Cardiol [Internet]. 2016[cited 2018 May 02];106(3):188-93. Available from: http://www.scielo.br/pdf/abc/v106n3/ pt_0066-782X-abc-20160025.pdf

10. Li P, Yang F, Xiong F, Huo T, Tong Y, Yang S, et al. Nutritional status and risk factors of overweight and obesity for children aged 9-15 years in Chengdu, Southwest China. BMC Public Health [Internet]. 2012[cited 2018 May 02];12:636. Available from: https://bmcpublichealth. biomedcentral.com/articles/10.1186/1471-2458-12-636

11. Garcez MR, Pereira JL, Fontanelli MM, Marchioni DML, Fisberg RM. Prevalence of dyslipidemia according to the nutritional status in a representative sample of São Paulo. Arq Bras Cardiol [Internet]. 2014[cited 2018 May 02];103(6):476-84. Available from: http://www.scielo. br/pdf/abc/v103n6/pt_0066-782X-abc-20140156.pdf

12. Bastos CCB. Culinária Mineira: tradição e saúde. Belo Horizonte: SESC Minas Gerais; 2009.

13. Bloch KV, Szklo M, Kuschnir MC, Abreu GA, Barufaldi LA, Klein CH, et al. The Study of Cardiovascular Risk in Adolescents - ERICA: rationale, design and sample characteristics of a national survey examining cardiovascular risk factor profile in Brazilian adolescents. BMC Public Health [Internet]. 2015[cited 2018 May 02];15:94. Available from: https://bmcpublichealth.biomedcentral.com/articles/10.1186/s12889-015-1442-X

14. Attard SM, Herring AH, Howard AG, Gordon-Larsen P. Longitudinal trajectories of BMI and cardiovascular disease risk: the national longitudinal study of adolescent health. Obesity [Internet]. 2013[cited 2018 May 02];21(11):2180-8. Available from: http://onlinelibrary. wiley.com/doi/10.1002/oby.20569/epdf

15. Pacifico L, Bonci E, Andreoli G, Romaggioli S, Di Miscio R, Lombardo CV, et al. Association of serum triglyceride-to-HDL cholesterol ratio with carotid artery intima-media thickness, insulin resistance and nonalcoholic fatty liver disease in children and adolescents. Nutr Metab Cardiovasc Dis [Internet]. 2014[cited 2018 May 02]; 24:737-43. Available from: https://www.ncbi.nlm.nih.gov/pubmed/24656140

16. Soares TS, Piovesan CH, Gustavo Ada S, Macagnan FE, Bodanese LC, Feoli AM. Alimentary habits, physical activity, and framingham global risk score in metabolic syndrome. Arq Bras Cardiol. [Internet]. 2014[cited 2018 May 02];102(4):374-82. Available from: http://www.scielo.br/ pdf/abc/v102n4/0066-782x-abc-20140029.pdf

17. Li S, Chen W, Srinivasan SR, Bond MG, Tang R, Urbina EM, et al. Childhood cardiovascular risk factors and carotid vascular changes in adulthood: the Bogalusa Heart Study. JAMA [Internet]. 2003[cited 2018 May 02];290(17):2271-6. Available from: https://jamanetwork.com/ journals/jama/fullarticle/10.1001/jama.290.17.2271

18. Magnussen CG, Raitakari OT, Thomson R, Juonala M, Patel DA, Viikari JS, et al. Utility of currently recommended pediatric dyslipidemia classifications in predicting dyslipidemia in adulthood: evidence from the Childhood Determinants of Adult Health (CDAH) Study, Cardiovascular Risk in Young Finns Study, and Bogalusa Heart Study. Circulation. 2008;117(1):32-42. doi: 10.1161/ CIRCULATIONAHA.107.718981

19. Ramos AT, Carvalho DF, Gonzaga NC, Cardoso AS, Noronha JAF, Cardoso MAA. Lipid profile in overweight children and adolescents. Rev Bras Crescimento Desenvolv Hum[Internet]. 2011 [cited 2018 May 02];21(3):780-8. http://pepsic.bvsalud.org/scielo. php?script=sci_arttext\&pid=S0104-12822011000300004\&lng=pt\&tIng=pt

20. De Franca E, Alves JG. Dyslipidemia among adolescents and children from Pernambuco. Arq Bras Cardiol[Internet]. 2006[cited 2018 May 02];87(6):722-7. Available from: http://www.scielo.br/pdf/abc/v87n6/07.pdf

21. Quadros TMB, Gordia AP, Silva RCR, Silva LR. Predictive capacity of anthropometric indicators for dyslipidemia screening in children and adolescents. J Pediatr (Rio J) [Internet]. 2015[cited 2018 May 02];91(5):455-63. Available from: http://www.scielo.br/pdf/jped/v91n5/16784782-jped-91-05-00455.pdf

22. Staiano AE, Gupta AK, Katzmarzyk PT. Cardiometabolic risk factors and fat distribution in children and adolescents. J Pediatr[Internet]. 2014[cited 2018 May 02];164(3):560-5. Available from: https://www.ncbi.nlm.nih.gov/pmc/articles/PMC3943888/pdf/nihms547345.pdf

23. Sociedade Brasileira de Cardiologia. I Diretriz de Prevenção da Aterosclerose na Infância e na Adolescência. Arq Bras Cardiol [Internet]. 2005[cited 2017 Nov 11];85(Suppl 6):3-36. Available from: http://dx.doi.org/10.1590/S0066-782X2005002500001

24. Ribas SA, Silva LCS. Dyslipidemia in Schoolchildren from Private Schools in Belém. Arq Bras Cardiol[Internet]. 2009[cited 2018 May 02];92:446-51. Available from: http://www.scielo.br/pdf/abc/v92n6/a06v92n6.pdf

25. Pires A, Martins P, Pereira AM, Silva PV, Marinho J, Marques M, et al. Insulin resistance, dyslipidemia and cardiovascular changes in a group of obese children. Arq Bras Cardiol [Internet]. 2015[cited 2018 May 02];104(4):266-73. Available from: http://www.scielo.br/pdf/ abc/2015nahead/pt_0066-782X-abc-20140206.pdf

26. Barbian CD, Burgos LT, Welser L, Sehn AP, Kern DG, Silva CF, et al. Comparison of the nutritional, lipidic and glycemic profile of children and adolescents of different hemispheres of the rural area of Santa Cruz do Sul - RS. Cinergis. [Internet]. 2017[cited 2018 May 02];18(2):140-5. Available from: https://online.unisc.br/seer/index.php/cinergis/article/viewFile/9018/5887

27. Santos MG, Pegoraro M, Sandrini F, Macuco EC. Risk Factors for the Development of Atherosclerosis in Childhood and Adolescence. Arq Bras Cardiol [Internet]. 2008[cited 2018 May 02];90(4):301-8. Available from: http://www.scielo.br/pdf/abc/v90n4/v90n4a12.pdf

28. Nobre LN, Sammour SNF, Costa Sobrinho PS, Elias FCA, Cavaca SCS, Trindade R, et al. Lipid profile and weight excess among school children. Rev Med Minas Gerais [Internet]. 2008[cited 2018 May 02];18(4):252-9. Available from: http://rmmg.org/artigo/detalhes/500 
29. Vodnala D, Rubenfire M, Brook RD. Secondary causes of dyslipidemia. Am J Cardiol[Internet]. 2012[cited 2018 May 02];1 10:823-5. Available from: http://www.ajconline.org/article/S0002-9149(12)01345-8/pdf

30. World Health Organization (WHO). Childhood overweight and obesity: WHO [Internet]; 2017[cited 2018 May 02]. Available from: http:// www.who.int/dietphysicalactivity/childhood/en/

31. Ribas SA, Santana da Silva LC. Anthropometric indices: predictors of dyslipidemia in children and adolescents from north of Brazil. Nutr Hosp [Internet]. 2012[cited 2018 May 02];27(4):1212-9. Available from: http://scielo.isciii.es/pdf/nh/v27n4/38_original27.pdf

32. Governo do Estado de Minas Gerais. Decreto Estadual 47.557, de 10 de dezembro de 2018. Dispõe sobre alimentos e produtos com comercialização permitida ou proibida no ambiente escolar nos termos da lei n 15.072, de 05 de abril de 2004. Resolução CAISANS/SEPLAG n 02[Internet]. Belo Horizonte, 2018[cited 2018 May 02]. Available from: https://www.educacao.mg.gov.br/ajuda/ page/17002-alimentacao-escolar-saudavel

33. Rodrigues AN, Abreu GR, Resende RS, Gonçalves WLS, Gouvea SA. Cardiovascular risk factor investigation: a pediatric issue. Int J Gen Med[Internet]. 2013[cited 2018 May 02];6:57-66. Available from: https://www.ncbi.nlm.nih.gov/pmc/articles/PMC3598497/pdf/ijgm-6-057.pdf

34. Catapano AL, Reiner Z, De Backer G, Graham I, Taskinen MR, Wiklund O, et al; European Society of Cardiology (ESC); European Atherosclerosis Society (EAS). ESC/EAS Guidelines for the management of dyslipidaemias: the Task Force for the management of dyslipidaemias of the European Society of Cardiology (ESC) and the European Atherosclerosis Society (EAS). Atherosclerosis [Internet]. 2011 [cited 2018 May 02];217(1):3-46. Available from: https://www.escardio.org/static_file/Escardio/Guidelines/publications/ DYSLIPguidelines-dyslipidemias-FT.pdf

35. Pratt CA, Loria CM, Arteaga SS, Nicastro HL, Lopez-Class M, Jesus JM, et al. A systematic review of obesity disparities research. Am J Prev Med. 2017;53(1):113-22. doi: 10.1016/j.amepre.2017.01.041

36. Cook S, Kavey RE. Dyslipidemia and pediatric obesity. Pediatr Clin North Am [Internet]. 2011[cited 2018 May 02];58(6):1363-73. Available from: https://www.ncbi.nlm.nih.gov/pmc/articles/PMC3220879/pdf/nihms323682.pdf

37. Lozano P, Henrikson NB, Dunn J, Morrison CC, Nguyen M, Blasi PR, et al. Lipid screening in childhood and adolescence for detection of familial hypercholesterolemia: a systematic evidence review for the us preventive services task force. Evidence Synthesis No. 141 [Internet]. Rockville, MD: Agency for Healthcare Research and Quality; 2016[cited 2018 May 02]. AHRQ Publication No. 14-0524-EF-2. Available from: https://www.ncbi.nlm.nih.gov/pubmedhealth/PMH0089073/pdf/PubMedHealth_PMH0089073.pdf

38. Campos W, Stabelini NA, Bozza R, Ulbrich AZ, Bertin RL, Mascarenhas LPG, et al. Physical activity, lipid consumption and risk factors for atherosclerosis in adolescents. Arq Bras Cardiol[Internet]. 2010[cited 2018 May 02];94(5):601-7. Available from: http://www.scielo.br/pdf/ abc/v94n5/aop02810.pdf

39. Catalano RF, Fagan AA, Gavin LE, Greenberg MT, Irwin Jr CE, Ross DA, et al. Worldwide application of prevention science in adolescent health. Lancet [Internet]. 2012[cited 2018 May 02];379 (9286):1653-64. Available from: https://www.thelancet.com/journals/lancet/article/ PIIS0140-6736(12)60238-4/fulltext 